\title{
SOVIET TREATY LAW: A QUANTITATIVE ANALYSIS
}

\author{
JAN F. TrISKA*
}

\section{INTRODUCTION}

The purpose of this paper is to discover and define, by way of quantitative analysis of Soviet treaties and Soviet treaty-making data, the more recent trends, tendencies, developments, conditions and propensities characteristic of the Soviet law of treaties. ${ }^{1}$

It is true that an analysis based on quantitative or "hard" data does not necessarily possess greater evidential weight than an analysis based on qualitative or "soft" data. This depends upon the problem under investigation. A rigorous content analysis ${ }^{2}$ of Plato's writings, for example, would tell us little about Plato's philosophy and ideology, try as we may, though it may yield less exalted information not obtainable otherwise. On the other hand, there are legitimate questions which can be answered through quantitative inquiry better than any other way. For example, the question whether relations among states depend upon and are conditioned by the volume, scope, frequency, type, and speed of the inter-state transactions, can best be answered quantitatively by any analysis of the transactional data correlated with an empirical scale of relationships between states.

The questions raised in this paper from the evidence and data gathered, explored, cross-examined and compared are entirely modest. They are directed to what may be called the "hard core" of Soviet foreign policy-i.e., that component of policy which expresses articulation and normalization of relationships, commitments, stability, conservation of forces but assimilation to change and concession to progress, resolution of conflicts, and attempt for creation of more favorable situations -namely treaties, agreements, and conventions. These questions are based on comparison of Soviet treaties - (I) their numbers, (2) contracting parties, and (3) typesin the 1958 -rg6I period with that of (a) the 1917-1957 period and, in some instances, with (b) the last four years of the 1917-1957 period, namely 1953-r957. The units of analysis are Soviet agreements and treaties, the time span is forty-five years, and the technique is comparative. The overriding interest here is the relation of data to hypotheses construction: The multiform interaction data upon which the research rests are used either to formulate or to test hypotheses.

I.U.D. 1948, Charles University (Prague); LL.M. 1950, J.S.D. I952, Yale University; Ph.D. 1957, Harvard University. Associate Professor and Associate Executive Head, Political Science Department, and Director, Studies of the Communist System, Stanford University.

${ }^{1}$ I am indebted to Professor Richard R. Brody of the Institute of Political Studies, Stanford University, for comments on and criticism of this paper; and to Messrs. Stephen R. Fox and William L. Tuohy of the Department of Political Science, Stanford University, for their research assistance.

${ }^{2}$ By content analysis is meant a systematic attempt to codify the matter contained in a defined set of communications with a view of obtaining measures of the substantive material contained in it. 
The quantification of Soviet agreements is, of course, only a prelude to the subsequent analysis-an essential prelude to the main theme. It is the analytical portion of the paper which contains the major effort, namely (I) finding the amount of change in the new data, (2) ascertaining the strength of relationship among the new data, (3) defining, on the basis of different particular ranges of data within the three groups, the degree of change over the whole range of data, and (4) discovering the degree of correlation between the data and the social reality in which the agreements were made. To this end, a set of hypotheses either emerging from or based upon the quantification of the data is offered in the last portion of the paper.

\section{NuMbBers}

In the four-year period between January I, I958, and December 3I, I96I, the U.S.S.R. allegedly concluded 870 international engagements-793 bilateral and 77 pluri- or multilateral. ${ }^{3}$ Compared with the 2,586 international arrangements Soviet Russia was purported to have concluded in the first $4 \mathrm{I}$-year period of its existence (2,086 bilateral and 500 pluri- or multilateral), ${ }^{4}$ as well as with the total of 702 agreements it concluded in the I953-1957 period, the record of the four most recent years makes it abundantly clear that the U.S.S.R. increases its contractual engagements over time, and substantially so. In fact the tendency noted in our book in $1962^{5}$ has been amply validated by the more recent data.

The average annual number of Soviet contractual engagements for the I9I7-I957 period (leaving out the brief and relatively unproductive year of $x 917$ ) was 62.9; in the r953-r957 period, the annual average was almost tripled to I75.5 agreements (in this four-year period the Soviet government concluded twenty-eight per cent of all its contractual engagements for the $4 \mathrm{I}$-year period); and in the r958-r96r period, the average jumped to 217.5 agreements per year-a 23.9 per cent increase over the previous four-year period but a truly spectacular increase of 246 per cent over the previous 4I year period. This dramatic increase in frequency and volume of Soviet treaties took place, however, in the bilateral sector: While the I9I7-1957 yearly plurilateral and multilateral average was 17.5 agreements and conventions, the 1958-196r yearly average increased only by ten per cent to 19.3 conventions and agreements. The Soviet government thus continued to favor bilateral over both plurilateral as well as multilateral arrangements, and increasingly so: While the I9r7-I957 ratio of the former to the two latter combined was over four to one, the

' Slusser \& Ginsburgs, A Calendar of Soviet Treaties, January-December 1958, 7 OsT EUROPA RECHT ro0-3I (1961). Ginsburgs \& Slusser, $A$ Calendar of Soviet Treaties, January-December 1959, 8 OST Ennopa Rechr 132-64 (1962); and Ginsburgs, $A$ Calendar of Soviet Treaties, January-December 196o, 9 Ost Europa Recht 120-59 (1963), and A Calendar of Soviet Treaties, January-December r96r, Io OST EuRopa RECHT II6-48 (1964).

'Robert M. Slusser \& Jan F. Triska, A Calendar of Soviet Treaties, igi7-r957 (I959).

- Jan F. Triska \& Robert M. Slusser, The Theory, Law, and Policy of Soviet Treaties 4 (I962). 
1958-196r ratio of bilateral to pluri- and multilateral treaties was over ten to one, or more than double that of the $4 \mathrm{I}$-year average.

Tested against new empirical evidence, then, our original hypothesis has been amply validated: The U.S.S.R. indeed tends to increase the number of its contractual commitments over time, strikingly so in the bilateral sector but only moderately in the pluri- and multilateral sector, i.e., on the regional as well as on the international levels.

\section{II}

\section{Contracting Parties}

In the r958-Ig6I period, the U.S.S.R. entered into bilateral contractual engagements with 65 states. However, it concluded 706 or about ninety per cent of all of its agreements with only $3^{6}$ of these states. Of these, 55.3 per cent were with the other I3 communist party-states ${ }^{6}$ (sixty-five per cent of these with the East European communistic party-states), 29.0 per cent with the developing countries, 9.0 per cent with the leading Western states and 6.5 per cent with Finland (24 agreements), Austria, and Japan (II agreements each).?

The comparison of the more recent data with data gathered previously indicates that alterations and changes here took place along the functional-ideological continuum and away from geographical orientation. In the I9I7-1957 period, the fifteen leading Soviet treaty partners were (1) Finland, (2) Poland, (3) Germany (and West Germany), (4) Romania, (5) Communist China, (6) and (7) Czechoslovakia and Bulgaria, (8) Hungary, (9) Yugoslavia, (ro) East Germany, (xx) France, (12) the United Kingdom, (13) Italy, (I4) Norway, and (I5) Albania. They were thus primarily Soviet neighbors (and their neighbors' neighbors) and secondarily leading West European countries. The reshuffling which took place in the 1958-196r periodto (I) Poland, (2) Bulgaria, (3) Mongolia, (4) Czechoslovakia, (5) Hungary, (6) East Germany, (7) and (8) North Korea and Romania, (9) India, (10)-(12) China, North Vietnam and Indonesia, (13) and (I4) Afghanistan and Finland, (15) Cuba, (I6) and (I7) Albania and Ghana, (I8) UAR, (19) Yugoslavia, (20)-(22) United Kingdom, United States and Guinea, (23) France, (24) West Germany, (25) and (26) Cambodia and Iraq-affected both categories: (A) As to the neighbors' group, the switch was (a) towards the communist party-states of Eastern Europe, the economically accelerated part of the socialist camp, namely (I) Poland, (2) Bulgaria, (4) Czechoslovakia, (5) Hungary, and (6) East Germany, all members of the Council of Mutual Economic Assistance and of the Warsaw Pact, and in the case of

\footnotetext{
'By communist party-states I mean those $I_{4}$ states which are ruled by communist parties, namcly, the U.S.S.R., the Chinese People's Republic, People's Republic of Albania, People's Republic of Bulgaria, Hungarian People's Republic, Democratic Republic of Vietnam, German Democratic Republic, Korcan Pcople's Democratic Republic, "Heroic People of Cuba," Mongolian People's Republic, Polish Pcople's Republic, Romanian People's Republic, Czechoslovak Socialist Republic, and Socialist Federal Republic of Yugoslavia. Cf. Pravda, April 14, I964, p. I.

7 The Soviet-Austrian agreements fall into the diplomatic formalities and trade agreements categorics while Soviet-Japanese engagements deal chiefly with fisheries and trade.
} 
TABLE I

Soviet Bilateral Contracting Parties

\begin{tabular}{|c|c|c|c|c|}
\hline \multicolumn{2}{|l|}{$1917-1957$} & \multicolumn{3}{|c|}{$1958-1961$} \\
\hline $\begin{array}{l}\text { Contracting } \\
\text { Rank Party }\end{array}$ & $\begin{array}{l}\text { Treaties \& } \\
\text { Agreements }\end{array}$ & Rank & $\begin{array}{c}\text { Contracting } \\
\text { Party }\end{array}$ & greements \\
\hline $\begin{aligned} 1 & \text { Finland } \\
2 & \text { Poland } \\
3 & \text { Germany (\& West Germany) } \\
4 & \text { Rumania } \\
5 & \text { Communist China } \\
6-7 & \text { Czechoslovakia \& Bulgaria } \\
8 & \text { Hungary } \\
9 & \text { Yugoslavia } \\
10 & \text { East Germany } \\
11 & \text { France } \\
12 & \text { Onited Kingdom } \\
13 & \text { Italy } \\
14 & \text { Norway } \\
15 & \text { Albania }\end{aligned}$ & $\begin{array}{r}134 \\
127 \\
107 \\
81 \\
73 \\
70\end{array}$ & $\begin{array}{l}1 \\
2 \\
3 \\
4 \\
5 \\
6 \\
7-8 \\
\\
9 \\
10-12 \\
13-14 \\
15 \\
(16-17 \\
18 \\
19 \\
20-22 \\
23 \\
24 \\
25-26 \\
27-29 \\
30-33 \\
34-37 \\
38-40\end{array}$ & $\begin{array}{l}\text { Poland } \\
\text { Bulgaria } \\
\text { MPR (Mongolia) } \\
\text { Czechoslovakia } \\
\text { Hungary } \\
\text { GDR (East Germany) } \\
\text { KPDR (North Kores); } \\
\text { Rumania } \\
\text { India } \\
\text { CPR (China); DRV (North } \\
\text { Vietnam); Indonesia } \\
\text { Afghanistan; Finland } \\
\text { Cuba } \\
\text { 7 Albania; Ghana } \\
\text { UAR (Egypt) } \\
\text { Yugoslavia } \\
\text { U.K.; U.S.; Guinea } \\
\text { France } \\
\text { FGR (West Germany) } \\
\text { Cambodia; Iraq } \\
\text { Austria; Italy; Japan } \\
\text { Iran; Ethiopia; Norway; } \\
\text { IMoroco } \\
\text { Nepal; Sudan; Brazil; } \\
\text { Ceylon } \\
\text { Iceland; Tunisia; } \\
\text { Somalia) }\end{array}$ & $\begin{array}{r}58 \\
39 \\
35 \\
33 \\
32 \\
30 \\
28 \\
27 \\
\\
25 \\
24 \\
22 \\
19 \\
18 \\
17 \\
16 \\
13 \\
12 \\
11 \\
8 \\
7 \\
6\end{array}$ \\
\hline
\end{tabular}

Bulgaria, Czechoslovakia and Hungary also members of the Danube Commission, and (b) away from the economically decelerated Asian portion of the camp, chiefly Communist China (from 5 th to Io-I2th place), but also North Korea (from 45th in 1957 to $7-8$ th place) and North Vietnam ( $13^{\text {th }}$ in 1957 , ro to I2th in $195^{8-1961)} .{ }^{8}$ Predictably, Mongolia moved contractually much closer to the U.S.S.R., while Albania came to be grouped with the Far Eastern party-states. Just as predictably, the now "neutralist" Yugoslavia moved from gth to Igth place on the Soviet contractual scale." On the other hand and significantly, Romania slipped from 4th $^{\text {th }}$ place

${ }^{8}$ With Communist China, North Korea and North Vietnam the U.S.S.R. concluded two, six, and six agreements respectively for industrial aid in this time period, while it concluded fifteen and twelve agreements with Bulgaria and Poland. Trade, scientific-technical aid, and economic agreements bear out the same or similar frequency-volume patterns.

- The Soviet Union concluded seventeen agreements with Yugoslavia-two in 1958, four in I959, five in 1960 , and six in 1961. Of these seventeen agreements, four were constituted by the protocol and plan of cultural and scientific collaboration between the Soviet Union and Yugoslavia (for the years 1958, 1959, I960, and I96r). This agreement covered the fields of art, science, cinema, higher education, publishing, radio and television. Similar plans were agreed upon by the Soviet Union and each of the other twelve communist party-states; they seem to be designed for the maintenance of and increase in ideological unity and understanding.

Four more of the eleven Soviet-Yugoslav agreements dealt with the work of the Soviet-Yugoslav 
to the $7-8$ th place, thus suggesting already at this time the cooling off of SovietRomanian economic relations, which became obvious to us only last year. Cuba moved from nowhere [except for the establishment (in 1942) and suspension (in I952) of diplomatic relations, no Soviet-Cuban agreements existed prior to 1960$]$ to I $5^{\text {th }}$ place in Ig6I with a spurt of 22 agreements, ${ }^{10}$ thus within two years approaching the four year records of Communist China and North Vietnam with 25 agreements each. (This Soviet-Cuban rapprochement is somewhat reminiscent of the I955 Soviet-Yugoslav renewal of relations, with its I8 Soviet-Yugoslav agreements.) Finland moved from first to 13 -I 4 th place on the Soviet contractual scale, an indication of growing functional disaffinity between the U.S.S.R. and Finland, ${ }^{11}$ and

commission on scientific-technical cooperation. There are similar Soviet commissions with the other communist party-states, apparently another measure for cohesion within the party-states system.

Of the three other agreements between the Soviet Union and Yugoslavia, one is a consular convention and the other two trade agreements-perhaps the only two agreements of the eleven of any actual consequence. Entered into on January 28 , 1959, and January 30, 1960, respectively, the 1959 plan called first for the exchange of Yugoslav steel pipes, rolled ferrous metals, lead, copper sheets, leather wear, mercury, cables, cement and woolens for Soviet wheat, coal, oil and oil products, rolled ferrous metals, tin sheets, wire, ferrous alloys, asbestos, manganese ore, machinery and equipment, medicines and chemicals, and so on; the 1960 plan was similar, but included a call for \$108 million worth of trade both ways.

The six agreements concluded in $196 \mathrm{r}$ concerned cultural matters (3 agreements), trade (2 agree. menits) and technical-scientific matters ( 1 agreement).

${ }^{10}$ On February 13, 1960, three agreements were concluded between the Soviet Union and Cuba: A joint communique concerning a visit by Anastas Mikoyan to Cub2; a trade and payments agreement (a) in which the Soviet Union promised to purchase one million tons of sugar annually for the next four years, and (b) creating a Sovict-Cuban mixed trade commission; and a credit agrecment providing Soviet credit to Cuba of up to \$100 million at $2.5 \%$ per annum. One week later an exchange of notes took place between the U.S.S.R. and Cuba concerning a provisional Soviet trade mission in Cuba. After these agreements were concluded, diplomatic relations were finally re-established between the two contracting parties on May 8, $x 960$.

The Soviet-Cuban relationship became even closer on June 18,1960 , when the two partners issued a joint communique on trade and economic questions and another on cultural relations; they also signed an' agreement on delivery of Soviet oil and oil products; and an agreement (between the State Bank of the U.S.S.R. and the National Bank of Cuba) on procedure for payments for goods delivered in accordance with the agreement on trade and payments and the agreement granting a Sovict loan to Cuba. All this, together with the final joint communique issued by the U.S.S.R. and Cuba on talks concerning trade, economic, and cultural relations of June 20, 1960, made Cuba a Soviet contracting partner high on the Soviet treaty scale. A month later, Raul Castro visited the U.S.S.R. and expressed Cuban gratitude for Soviet political and moral support and economic aid. He said he appreciated the Soviet readiness to use any means to prevent an armed attack on Cuba by the United States.

Later in I960, Cuba and the U.S.S.R. agreed to employ Soviet technical aid in Cuban industry and geological survey work, and to send Cuban specialists and technicians to the U.S.S.R. for training. Other contractual engagements concluded before the year's end included an agreement on cultural cooperation; a trade protocol for I96I based on the agreement on February 13, 1960, and foresceing an increase in trade turnover; an agreement for Soviet technical aid in geological prospecting for oil and other minerals; an agreement providing for Soviet aid in the training and education of Cuban specialists in various fields of the national economy; and a joint communique issued after Guevara's visits to the U.S.S.R.-concerning international questions, trade, and scientific and cultural cooperation.

- In I96I, Cuba concluded four more agreements with the U.S.S.R. - on technical-scientific, technicalindustrial, cultural and economic cooperation.

${ }^{21}$ Against the Soviet-communist party-states' agreements, the twenty-four Soviet-Finnish agreements of r957-r96r appear quite non-committal. There are some settlements of claims, agreements on border and customs regulations, agreements concerning fishing and navigation, and renewals of trade protocols. There is only one agreement providing for Soviet-Finnish industrial-technical cooperation, and only three agreements which deal with broader economic problems. 
Norway was displaced, from I4th to 29-32nd place, by more responsive Soviet contractors from Asia and Africa.

(B) The leading West European states all disappeared from their relatively high

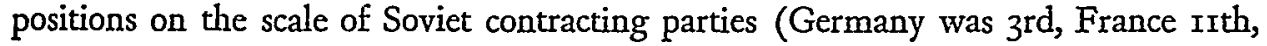
the United Kingdom 13th, and Italy I4th) and reappeared outside of the fifteen leading Soviet treaty partners, namely in the 20th-23rd and 26-28th places. Also, a certain amount of switching around took place: A non-European power, the United States, moved into the lead and became now with the United Kingdom the ranking Soviet treaty partner from the West (20-22nd on the scale both with 16 agreements), followed by France (23rd with I5 agreements), West Germany (24th with I3 agreements), and Austria and Italy (27-2gth with II agreements).

(C) The leading West European states were displaced on the Soviet contractual scale by the developing states of Asia and Africa-India ( 9 th), ${ }^{12}$ Indonesia (IOI2th) ${ }^{13}$ and Afghanistan (13-r 4 th).$^{14}$ These favorable Soviet contractual respondents were followed by Ghana (I6-I th place), United Arab Republic (I8th), Guinea (2022nd place), Cambodia and Iraq (25-26th), Morocco, Iran, and Ethiopia (30-33rd), Nepal, Sudan, Brazil and Ceylon (34-37th) and Iceland, Tunisia, and Somali (384oth).

\section{III}

\section{CONTENT}

Robert Slusser and the present author maintained in 1962 that the U.S.S.R. concluded chiefly trade and commercial agreements: about every third Soviet agree-

\footnotetext{
${ }^{12}$ Soviet-Indian contractual interactions fall primarily into the spheres of trade and industrialtechnical aid agreements. The Soviet Union decided to aid India in the construction of a thermal power station, in construction of an oil refinery, and in geological survey work in the extraction of oil and gas. The Soviets gave assistance to the Indian Technological Institute for the training of engineers and technical aid to Indian agriculture; provided for Indian industrial specialists to come to the U.S.S.R. to study; sent Soviet specialists to India to work and train Indian specialists; and agreed to build Indian industrial complexes through mutual cooperation. Soviet officials visited India three times (including a visit by Premier Khrushchev). A five-year trade agreement between the two nations was signed on November $16, x 958$, and another agreement "foreseeing a considerable increase in the variety and volume of trade" was signed in March, 1960. Finally, a Soviet-Indian credit agreement providing a Soviet credit of $\mathrm{r} .5$ billion rubles aver twelve years was concluded in September, 1959.

Nevertheless, India's interaction with the West was higher, in the 1958-rg6I period, than with the U.S.S.R.

${ }^{13}$ The U.S.S.R. granted a large amount of credit to Indonesia. On July 28, 1959, the U.S.S.R. supplemented the $\$ 100$ million credit granted three years earlier to Indonesia by providing a $\$ 12.5$ million credit for building a I00,000 seat stadium in Djakarta (to be ready for the Asian Games in 1962). On that same day, the Soviets granted an additional credit of $\$ 5$ million for construction of a technological faculty in Ambon and for training Indonesian specialists. A Soviet-Indonesian agreement of February 28, x960, provided for a Soviet long-term (seven years) credit of $\$ 250$ million for help in the use of atomic energy for peaceful purposes, construction of works associated with this field, and training of specialists. The I $96 \mathrm{r}-\mathrm{Ig} 63$ trade agreement between the U.S.S.R. and Indonesia, signed on July 9, I960, called for trade to increase yearly; in 1963 to be thrice the amount of 1959 .

${ }^{16}$ The Soviet-Afghanistan pattern of agreements exhibits a remarkable similarity to that of the Soviet-East European communist party-states. The technical-scientific, technical-industrial, technicalsgricultural, cultural and trade and commerce agreements are all there, and in high numbers. Afghanistan ranks on the Soviet treaty scale as high as Finland.
} 
ment or treaty during this period concerned trade or commercial issues and problems. The second largest group of Soviet contractual engagements, or slightly less than one-fourth of the total, dealt with political problems ranging from formal issues of diplomatic relations (I74 agreements) to treaties of alliance and fraternal mutual assistance (414). The remaining Soviet agreements and treaties concerned so-called functional problems, oscillating from many-legal issues, communication, transportation and cultural problems-to few-technical military questions, armistices and suspension of hostilities, and territorial questions.

In view of the somewhat changed character and content of the agreements encountered in the I958-I96r period, it seemed preferable to let the new data form the categories rather than force the former categories on the new data. As a consequence, the classification employed here is slightly different from that used in our previous study. The $x_{4}$ new categories embrace international contractual engagements dealing with (I) trade and commerce (202 agreements); (2) technical-economic aid in areas of industry and industrial production ( 136 agreements); (3) diplomatic affairsrecognition of states and governments, exchanges of ambassadors, establishment of relations, diplomatic visits, consular conventions, and so on (rro agreements); (4) cultural issues, including cultural and educational exchanges and assistance and collaboration in science (IIO); (5) scientific questions and technical aid in scientific and cultural problems (87); (6) economic aid, payments agreements, economic collaboration and credit agreements (79); (7) matters dealing with international waters, navigation, and fishing (35); (8) matters of transportation, customs, travel, citizenship, and border demarcation (29); (9) issues of communication (18); (10) tech. nical-economic aid in areas of agricultural and/or geological development (I6); (II) matters concerning peaceful uses of atomic energy and disarmament (20); (12 and I3) health problems, social security plans, and aid in building hospitals (ro), and settlements of international claims (Io); and (I4) military aid or other military issues (8).

The I4 categories include both bilateral as well as pluri- and multi-lateral engagements; of the latter, the highest number concerns matters dealing with international waters, navigation, and fishing (15) and diplomatic and consular affairs (15); matters of transportation, customs, and travel (II); economic aid and payments agreements (8); and issues of communications (6).$^{15}$

\footnotetext{
${ }^{15}$ Included in this number are meetings of the Soviet-sponsored Danube Commission, those of the Council for Mutual Economic Aid, the Joint Institute for Nuclear Research protocol on further cxpression of scientific collaboration, and the meetings and declarations of the members of the Warsaw Pact. Also, agreements such as the International Convention for the Northwest Atlantic Fisheries and thirtecn other multilateral agreements in the spheres of international waters, regulation of vessels, or regulation of fishing were concluded. Other agreements concern such matters as telegraph regulations, protocol on road signs and signals, convention concerning customs facilities for touring, and so forth. Also included are the several agreements which the U.S.S.R. concluded as a part of the business of the United Nations.

Agreements of an international multilateral scope which were of political interest were those in which the subjects of Berlin or nuclear disarmament arose. On September $x-14,1958$, the Sovict Union participated in the Second United Nations Conference on Peaceful Uses of Atomic Energy. On August 30,
} 
Comparing the above cross-classification with the results contained in our previous study, the new data tell us the following: ( $I$ ) The major categories concerning economic issues and questions (namely trade and commerce; economic aid, payments agreements, etc.; technical economic-industrial aid; and technical economicagricultural aid) total 433 agreements or 49.7 per cent, a 15.4 per cent increase over the $4 \mathrm{I}$ year period. (2) The change is even more striking with reference to the political treaties. Even if we include, in addition to the legitimate diplomatic affairs category (I00 agreements), the more questionable categories of peaceful uses of atomic energy (and disarmament) agreements (20) as well as the military aid agreements (8), the total amounts to a mere 138 agreements or 15.8 per cent of all the agreements concluded in this period. Not only does this represent a drop of eight per cent from the previous long period, but the political treaties-the solemn treaties of alliance, mutual political assistance, non-aggression, peace, and so onare entirely missing here, a truly striking change from the past. (3) With reference to the functional group, changes have occurred as well: armistices and suspensions of hostilities, just as repatriation problems, do not appear in this time period. The former legal category tends to appear in the form of socio-cultural aid. Instead of the humanitarian questions category, the more satisfactory technical, scientific and cultural aid categories have been employed. Health questions re appear in the I958-I96r period, and the U.S.S.R. continued to agree to help solve them. The communication and transportation categories remain as well. All in all, the functional groups, formerly 40.1 per cent strong, declined only 6.8 per cent to

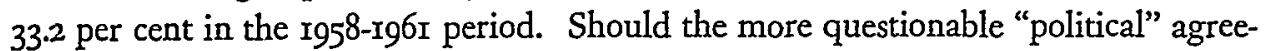
ments concerning military aid and peaceful uses of atomic energy be included at least partly here, the functional group would show increase rather than remaining much the same. In any case, the major changes here occurred in the aid and assistance agreements-cultural, scientific, technical-where the numbers of agreements have risen sharply in the $195^{8-1961}$ period.

All in all, Soviet economic agreements showed a sharp rise; Soviet political agreements dived into decline (in fact, "solemn" political treaties disappeared al-

the United States and the United Kingdom announced declassification of information on controlled thermonuclear reactions; the U.S.S.R. made a similar announcement on September I. October $3 \mathbf{I}$ through December 19, 1958, was the time of the Geneva conference on the discontinuance of nuclear weapons tests. At the time, the most important result was the tacit de facto agreement on cessation of nuclear tests by the U.S.S.R., United States and Great Britain. In reply to Soviet notes proposing a summit conference of Heads of Government, of March 2, 1959, to take place at the end of April in Geneva or Vienna, the Western Powers agreed. As a result the conference in Geneva met on May II to discuss questions relating to Germany and Berlin. The first half of this meeting was held from May II to June 20, and the second half from July 13 to August 5. The final communique mentioned "frank and comprehensive discussion" of the Berlin question and stated that the discussions would be "useful for the further negotiations which are necessary in order to reach an agreement."

On September 8, r959, a joint communique was issued by the Foreign Ministers of France, the United States, Great Britain, and the U.S.S.R., concerning creation of a committee for the study of questions of disarmament. Finally, on December 30, 1959, there was an exchange of notes concerning a Four Power Conference "to discuss the main problems affecting the attainment of peace and stability in the world." The four contracting parties agreed to meet on May 16, 1960, in Paris. 
TABLE 2

Classifications of Soviet Agreements According to Their Content

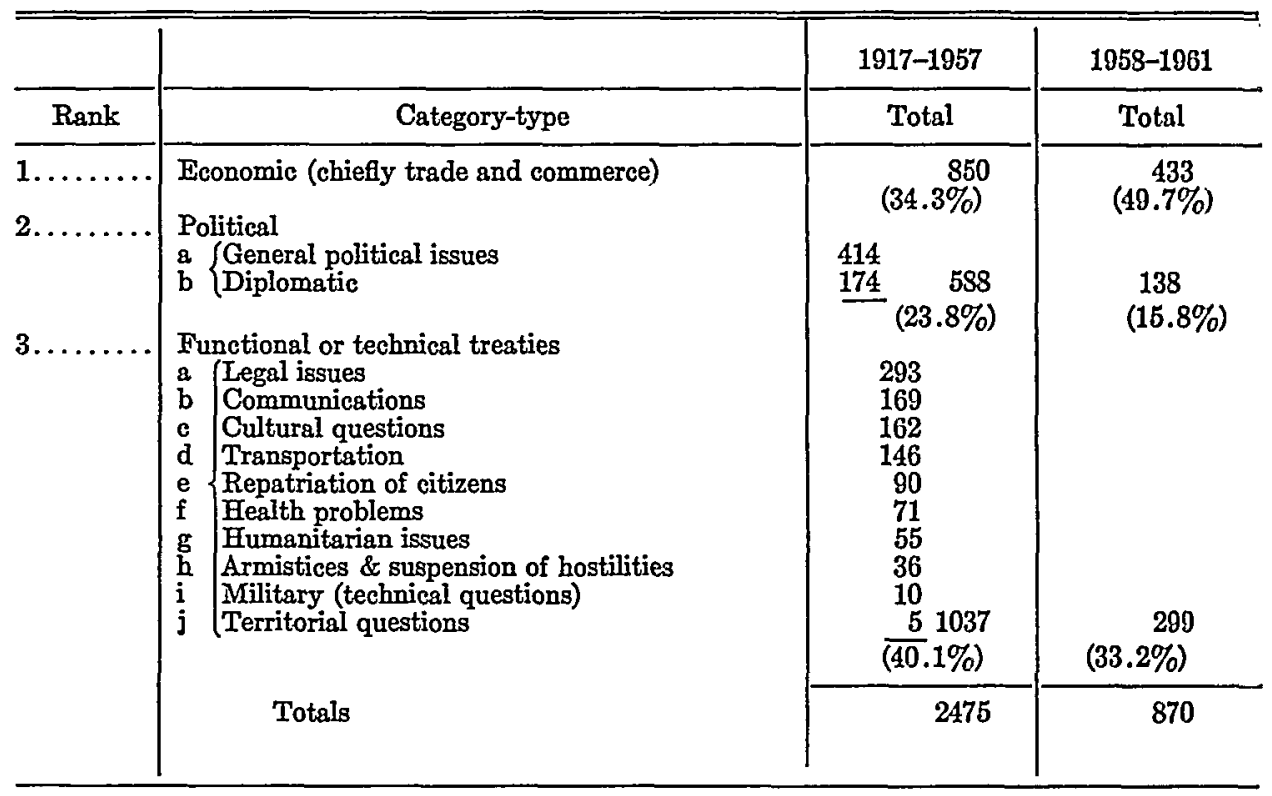

\begin{tabular}{|c|c|c|c|c|}
\hline \multicolumn{5}{|c|}{$1958-1961$} \\
\hline $\begin{array}{l}\text { Rank on } \\
\text { totals }\end{array}$ & Category-type & $\begin{array}{c}\# \\
\text { Bilateral }\end{array}$ & $\begin{array}{c}\# \\
\text { Pluri -\& } \\
\text { Multi- } \\
\text { lateral }\end{array}$ & Total \\
\hline \multirow{8}{*}{ 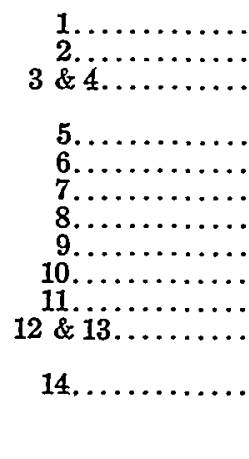 } & \multirow{8}{*}{\begin{tabular}{l} 
Trade and commerce \\
Techmical-industrial \\
\{Cultural \\
[Diplomatic \\
Technical-scientific \\
Economic \\
Fishing; int' waters \\
Transportation, customs, travel \\
Disarmament; peaceful atomic uses \\
Communications \\
Technical-agricultural \\
Settlement of claims \\
Health problems \\
Military \\
\multicolumn{1}{c}{ Totals }
\end{tabular}} & \multirow{7}{*}{$\begin{array}{r}198 \\
132 \\
110 \\
95 \\
82 \\
71 \\
20 \\
18 \\
14 \\
12 \\
14 \\
10 \\
9 \\
8\end{array}$} & \multirow{7}{*}{$\begin{array}{r}4 \\
4 \\
0 \\
15 \\
5 \\
8 \\
8 \\
15 \\
11 \\
6 \\
6 \\
2 \\
0 \\
1 \\
0\end{array}$} & \multirow{7}{*}{$\begin{array}{r}202 \\
130 \\
110 \\
110 \\
87 \\
79 \\
35 \\
29 \\
20 \\
18 \\
10 \\
10 \\
10 \\
8\end{array}$} \\
\hline & & & & \\
\hline & & & & \\
\hline & & & & \\
\hline & & & & \\
\hline & & & & \\
\hline & & & & \\
\hline & & 793 & 77 & 870 \\
\hline
\end{tabular}

together); and Soviet functional agreements, shifted into new categories, mildly gained in number.

The quantification of Soviet treaty data which produced the above findings yielded the following hypotheses: 
(I) The rapidly diminishing cultural, social and economic homogeneity of the expanding international system; the constantly accelerating pace of international relations; the instant and dire need in new areas for fresh and imaginative approaches and solutions, more often than not brought about by rapid technical and technological advances; and the increasing inadequacy of international custom and customary law (sure but slow) in the new situations-clearly emerge as the reasons that favor international agreements over other interstate means and solutions. Rational, specific, adaptable, stabilizing, equitable, innovating, flexible, proportionate and rapid, international agreements appear to offer solutions in situations where no other available tools seem to work. Not unlike the other units in the international system in this respect, the U.S.S.R. finds itself constantly augmenting and amplifying its international contractual engagements.

(2) Forty-seven years after its uneasy beginning, the Soviet Union is a great world power. It has reached heights undreamed of by the revolutionary Bolsheviks. It is a powerful state, politically satiated for the time being by all standards, notwithstanding its ideological claims to the contrary. It plays a crucial role in the international system which it helped to establish-and which it respects in its own way as much as its bourgeois partners do, even if this means the recognition of neutralism and neutrals in the world or acceptance of communist neutralism in Yugoslavia. The U.S.S.R. has traveled a long way since I9I7, but it has arrived. It is an established, powerful, have-state which is vesting a great deal of interest in the known present in contrast to the less certain future, and is unwilling to take excessive risks. The longer this. Soviet behavioral stance endures in the world system, the more likely international agreements will continue to serve the U.S.S.R. well.

(3) As a ranking member of the communist system, a subsystem of the international system, the U.S.S.R. has additional responsibilities. The growing restlessness of some of the units here as well as their growing propensity toward stratification, segmentation, heterogeneity, diversity, and conflict, appears to call increasingly into play those means of intercourse that are in harmony with the growing emphasis of the member units on cooperation which indeed is volitional, consensual, voluntary and permissive rather than primitively assertive. The more widely the shared demand for utility and functional integration based on mutual advantage appears to be dictating, in this stage of the communist community building, the kind of tools which should be used, the more likely will international agreements, with their decentralizing but assimilating qualities, appear to be ideal for that purpose.

(4) At the same time, however, the rapidly accelerating Soviet propensity toward contractual engagements and involvement appears to be making no appreciable dent in the older Soviet pattern of participation in bilateral rather than any other contractual engagements. Neither multilateral or world, nor plurilateral or communist system agreements have been appreciably rising, either in proportion to accruing 
Soviet responsibilities in either system or in proportion to the great spurt in its bilateral agreements.

(5) The volume and scope of the $195^{8}-196 \mathrm{r}$ Soviet contractual transactions and the compatibility, effectiveness, frequency, speed, and range of those transactions indicate changing Soviet relationships with the contracting parties. The objective contractual typology, however, appears to confirm the sentiment or commitment pattern:

(a) In terms of modernization and development, the several East European party-states are closer to each other and to the U.S.S.R. than to any other communist party-state. Given their ideological, social, historical, geographical, ecological, and system affinity, it is not unexpected that in terms of collaboration, coordination, integration, and supranational planning, the U.S.S.R. and Poland, Bulgaria, Czechoslovakia, Hungary, and East Germany would have a higher degree of contractual interaction among themselves than with other contracting parties.

The very high position of Mongolia on the Soviet scale of bilateral contracting parties is not entirely surprising. Still, Mongolia moved to the third place on the scale only in $196 \mathrm{I}$ with a spurt of 13 new agreements (from 6-7th place in 1960 with 22 agreements on its record then). Perhaps one of the most sensitive indicators of the intensity of the Sino-Soviet relationship, Mongolia continues to play this characteristic role.

(b) The developing Asian countries high on the Soviet contractual scale were sustaining an overall high degree of interaction with the U.S.S.R., as tested in another recent study ${ }^{\mathbf{1 6}}$ where an interactional input-output correlation between the U.S.S.R. and those "uncommitted" nations was found to exist at better than .oor level of significance (i.e., the probability was less than one in a thousand that the similarities in the orderings were due to chance) ${ }^{17}$ The interaction pattern thus offers an additional test of the overall interactional behavior of these nations.

(c) The leading Western states, themselves highly developed, can effectively assist the U.S.S.R. to speed up its own development as well as that of the most accelerated communist party-states' economies. Hence their high places on the scale.

(6) The observable Soviet propensity, growing over time, to conclude chiefly economic and trade but also functional, cultural and technical agreements instead of political treaties may be considerd to be due to the following causes:

(A) International relations, upset by the Second World War, were being resetby agreement, conflict, or default-in the decade after the war. The new setting had been accomplished de facto within five and de iure within to years. The

${ }^{16}$ Jan F. Triska with David O. Beim and Norazou Roos, The World Communist System (Stanford Studies of the Communist System, mimeo., 1964, 59 pp.).

12 The only exception was India, which could be termed the classic neutral; economically dependent on' the West but attempting to play the role of the "honest broker" between the two systems. Its average international input-output index (with the U.S.S.R.) had been found negative, i.e., closer to the West than to the communist system. Ibid. 
vanquished, which temporarily disappeared, had emerged again; the victors had decided who among them won the most; the liberated nations joined or were joined in new political systems; and the bulk of the former colonial but now developing nations had made their choices and cast their lot.

This was the time of decisions and actions greatly influencing subsequent developments, the international take-off period. The new systems-the socialist camp, the North Atlantic Treaty Organization, as well as the neutralist Asian-African alignment-were constructed at this time. The new political style in the world was set. The ideological commitments or impositions made at this crucial period froze into systems which permitted only limited defection, trading of partners and loyalties, deviations, or alienations. What followed after 1955 were at most amendments, not new constitutions. Politics gave way, as Engels once said, to administration. $^{18}$

This world trend is faithfully mirrored in the pattern of the I958-rg6r Soviet agreements. The constitutive and essential gave way to the administrative and the developmental. The former basic laws were now being implemented by multiplying and proliferating ordinances and decisions. The "solemn" treaties became simple agreements. The stage of Soviet development-in international relations, in the communist system as well as in the East European regional setting-was chronicled in the kinds of Soviet international engagements. They were more numerous, though politically less significant, than ever before.

(B) Seldom have international contractual and legal relations aroused so much sustained concern throughout the world as have Soviet treaties because of the alleged propensity to violate them. The distrust and suspicion thus evoked has not been associated with Soviet economic and trade agreements, nor with their functional, cultural or technical agreements, and not even with their formal political agreements concerning diplomatic and consular affairs. It has been associated primarily with their major "solemn" political treaties, and in particular those treaties and pacts guaranteeing the territorial integrity of the Soviet treaty partners as well as non-agression and non-interference in their domestic matters by the U.S.S.R.

And these are precisely those treaties missing in the $195^{8}$-r96I period. I submit that the lack of interest in concluding such treaties is probably mutual. It is conditioned by the past Soviet record, the lack of mutually perceived need, the hardening of the borders between the several systems throughout the world, and by the Soviet preference for "peaceful economic competition" with the West for the allegiance of the developing countries, the only soft border left in the world today.

\footnotetext{
${ }^{18}$ Friedrich Engels, Herrn Eugen Dührings UMwälzung der Wissenschaft (ANti-Dühtring) (3d ed. I894), reprinted in 20 KARL MARX, FrIedrich Engels, Werke I, 262 (I962).
} 


\section{Conclusion}

The Soviet policy propensity is to proliferate considerably its bilateral contractual engagements over time, chiefly in the economic, trade, and also the functional sphere, and with states which politically, economically and/or functionally are the closest to the U.S.S.R. What does this imply in terms of the more enduring tendencies, conditions, trends, and developments of Soviet treaty law and policy?

(I) With respect to the Soviet treaty law, I submit, it tends to diminish the dissimilarity to Western treaty law. The political-ideological orientation of Soviet treaty law noted in our 1962 study ${ }^{19}$ referred primarily to problems concerning unilateral termination of treaties, a problem disappearing with the disappearance of Soviet political treaties. With the observed tendency on the part of Soviet treatymaking toward political and economic advantage chiefly via economic utility and function, the trend has been from the ideological to the pragmatic and from the hegemonial to the consensual.

(2) With reference to the Soviet treaty policy, the new Soviet de-emphasis of the political treaties bias tends to confirm further our 1962 conclusion. We said then that improvement upon, rather than a risky challenge of, the status quo characterizes current Soviet treaty policy, and that the dominant accent is on economic and trade treaties and agreements. I would add now only that the trend appears to be even more clearly leading from "solemn" treaties to practical agreements, from political to economic engagements, from the normative to the descriptive, and from a high-faluting stochastic model to complex reality than we had suspected in 1962 .

(3) Finally, with regard to the conflictual nature of Soviet treaties, it appears that the earlier elimination of major and substantive areas of conflict leaves only minor peripheries and objectives for the contest, more significant to the contestants in alleged prestige value than in actual strategic worth. As reflected by the new agreements, the world of the U.S.S.R. is getting more complex, functional, utilitarian, pragmatic, and conservative. The contractual conflict dangers to the Soviet Union seem to be more threatening from the camp of its allies than from that of its adversaries. The Western states seem to have rejected both withdrawal from contact as unrealistic and integration of interests as unattainable. Observing the caveat emptor rule, they are in various degrees contractually involved with the U.S.S.R. in an attempt for mutual advantage, and benefit, and attainment of common interests. Both parties appear to agree now that agreements based on compromise make the new relationship preferable to the past non-treaty situation, and that specific compromises may be contributive to a gradual reduction of antagonism.

In fact, it is Communist China which has recently accused the U.S.S.R. of treaty violations, and on a large scale at that. According to an editorial in Hung Chi, the ideological journal of the Chinese Communist Party's Central Committee, and

\footnotetext{
19 TRISRA \& SluSSER, op. cit. supra note 5, at $\mathrm{r} 72$.
} 
reprinted by Jen Min Yih Pao, the Chinese Communist Party daily on February 4, 1964 ,

The leaders of the C.P.S.U. [Communist Party of the Soviet Union] have violated the Chinese-Soviet treaty of friendship, alliance and mutual assistance, made a unilateral decision to withdraw 1,390 Soviet experts working in China, to tear up 343 contracts and supplementary contracts on the employment of experts, and to cancel 257 projects of scientific and technical cooperation, and pursued a restrictive and discriminatory trade policy against China. ${ }^{20}$

Still, our hypotheses, either tested in or emerging from the quantification of our

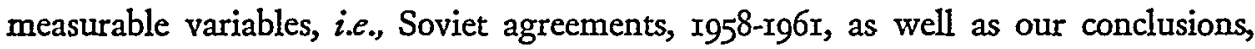
are based on limited data. Ideally, one should have (a) a larger sample, reaching as close as possible to the the present; (b) other interactional data for the same time period and contractual parties that could be coupled with the sample for greater depth; and (c) an elaborate and extensive content analysis of the texts of the treaties by electronic computers. ${ }^{21}$ At the present, these additional data are either unobtainable or, because of their marginal nature, too costly for the purpose.

${ }^{20}$ N.Y. Times, Feb. 7, 1964, p. C.

${ }^{31} \mathrm{Cf}$. Stone, Bales, Namenwirth \& Ogilvia, The General Inquirer: A Computer System for Content Analysis and Retrieval Based on the Sentence as a Unit of Information, 7 Befavioral ScIence 484 (Ig62). 